\section{Prohexadione-Ca and Ethephon Reduce Shoot Growth and Increase Flowering in Young, Vigorous Sweet Cherry Trees}

\author{
Don C. Elfving ${ }^{1}$, Gregory A. Lang ${ }^{2}$, and Dwayne B. Visser ${ }^{3}$ \\ Washington State University, Tree Fruit Research and Extension Center, \\ Wenatchee, WA 98801
}

Additional index words. plant growth regulators, bioregulators, Apogee, Ethrel, vegetative growth, bloom, precocity, fruiting, yield, gummosis, Prunus avium

\begin{abstract}
Prohexadione-Ca (P-Ca) and ethephon (ETH) were evaluated as potential inhibitors of growth and promoters of early flowering for high density orchard management of sweet cherry (Prunus avium L.) trees on vigorous rootstocks. Single applications (P-Ca at 125 to $250 \mathrm{mg} \cdot \mathrm{L}^{-1}$ active ingredient (a.i.) or ETH at 175 to $200 \mathrm{mg} \cdot \mathrm{L}^{-1}$ a.i.) to young, nonfruiting sweet cherry trees produced short-term, generally transient reductions in terminal shoot elongation, and did not stimulate flower bud formation. Tank-mix applications (P-Ca + ETH) usually produced a stronger, possibly synergistic, reduction in shoot growth rate. Single tank-mix applications either increased subsequent flower bud density on previous season shoots or had no effect; when a second application was made three weeks later to the same trees, subsequent flower bud density on previous season shoots and spurs on older wood increased $\approx 3$-fold over untreated trees. Yield efficiency $\left(\mathrm{g} \cdot \mathrm{cm}^{2}\right.$ trunk cross-sectional area) also increased nearly 3-fold. Chemical names used: (2-chloroethyl) phosphonic acid (ethephon); calcium 3-oxido-4-propionyl-5-oxo-3-cyclohexene carboxylate (prohexadione-Ca); polyoxyethylenepolypropoxypropanol, dihydroxypropane, 2-butoxyethanol (Regulaid); aliphatic polycarboxylate, calcium (Tri-Fol).
\end{abstract}

'Bing' sweet cherry represents nearly $90 \%$ of sweet cherry production in Washington state, most of which is planted on Mazzard seedling rootstock. This combination is very productive under Pacific Northwest (PNW) conditions, but takes 5 to 7 years to begin flowering and makes very large trees poorly suited to modern labor-efficient, higher density orchards. Use of precocious, dwarfing rootstocks for sweet cherry production has been controversial thus far due to difficulties in balancing increased crop loads with reduced tree vigor (Lang, 2000). While the advent of new fresh market sweet cherry cultivars has fueled a major increase in acreage planted in WA during the past 5 years, Mazzard has remained the general rootstock of choice, albeit creating a dilemma for growers needing to reduce labor costs and hasten early returns.

Vigorous shoot growth in sweet cherry trees can be controlled with gibberellinbiosynthesis inhibitors such as daminozide or paclobutrazol (Facteau and Chestnut, 1991; Facteau and Rowe, 1979; Looney and

Received for publication 1 Apr. 2002. Accepted for publication 28 June 2002. We wish to express appreciation to the Washington Tree Fruit Research Commission and to BASF Corp. and Bayer CropScience for funds partially supporting these studies.

${ }^{1}$ Horticulturist and Professor. To whom requests for reprints should be addressed. E-mail address: delfving@wsu.edu

${ }^{2}$ Professor, Current address: Dept. of Horticulture, Michigan State Univ., East Lansing, MI 488241325.

${ }^{3}$ Agricultural Technician II
McKellar, 1987; Proebsting and Mills, 1976; Stan et al., 1989; Webster et al., 1986), but these products are not commercially available in the United States. Prohexadione-calcium (P-Ca) was recently registered in the United States for vegetative growth control and fireblight management in apple under the trade name Apogee ${ }^{\circledR}$ (BASF Corp., Research Triangle Park, N.C.) (Unrath, 1999; Yoder et al., 1999). The principal mode of action of $\mathrm{P}-\mathrm{Ca}$ in reducing shoot elongation in fruit trees results from its inhibition of the biosynthesis of active gibberellic acid (GA) isomers in plant tissues (Evans et al., 1999; Rademacher, 2000). Effects of P-Ca on sweet cherry growth and flowering have not been described.

Ethephon [(ETH) Ethrel $^{\circledR}$, Bayer CropScience, Research Triangle Park, N.C.] has been reported to reduce vegetative growth in apple (Edgerton and Greenhalgh, 1969; Williams, 1972; Byers, 1993), but only a few spring applications of ETH on shoot growth of vigorous sweet cherry trees (Facteau and Rowe, 1979; Grzyb, 1982, Modlibowska, 1973). Facteau and Rowe (1979) observed increased flowering on 2-and 3-year-old wood the year following double applications of ETH to 'Napoleon' sweet cherry trees. Guimond et al. (1998) noted that ETH can increase sweet cherry flowering up to 6-fold but showed no data. The studies reported here were designed to evaluate the potential use of P-Ca and ETH to reduce shoot growth and/or increase flowering in nonfruiting young sweet cherry cultivars on Mazzard seedling rootstocks under PNW growing conditions. reports are known that describe effects of
Research plots were established in commercial orchards in locations near Wenatchee and Quincy (north-central Washington state), in one orchard at the Irrigated Agriculture Research and Extension Center (IAREC) of Washington State Univ. in Prosser (Yakima valley), and in a commercial orchard near Pasco (southern Washington). All experiments used single-tree plots in randomized complete-block designs. All spray solutions were supplemented with $0.1 \%$ v/v Regulaid (Kalo, Overland Park, Kan.), adjusted if necessary to a $\mathrm{pH}$ of about 5 with a commercial buffer (Tri-Fol, Wilbur-Ellis Co., Fresno, Calif.), and applied to run-off with hydraulic handgun equipment.

Trial 1 (1999). Nonfruiting 'Bing'/Mazzard trees planted in 1996 near Wenatchee (elevation $\approx 790 \mathrm{~m}$, four replicates per treatment) were treated on 18 June as follows: 1) no treatment (unsprayed control); 2) a single application of P-Ca $\left[250 \mathrm{mg} \cdot \mathrm{L}^{-1}\right.$ active ingredient (a.i.)]; 3) a single application of ETH $\left(175 \mathrm{mg} \cdot \mathrm{L}^{-1}\right.$ a.i.); or 4) a single application of a tank-mix of both products at the same concentrations as applied individually (terminal shoots $33.9 \pm$ $0.8 \mathrm{~cm}$ at time of applications). Shoot lengths were measured twice weekly on five marked terminal shoots per tree from the inception of the trial to the end of August, by which time terminal buds had already formed. Trunk circumferences were measured at $\approx 30 \mathrm{~cm}$ above the soil line at the inception of the trial and at the end of the growing season.

Trial 2 (2000). Nonfruiting 'Attika' (a/k/a 'Kordia'), 'Bing', and 'Regina' trees on Mazzard rootstocks planted in 1998 at the IAREC (elevation $\approx 340 \mathrm{~m}, 6$ replicates per cultivar) were treated on 25 May as follows: 1) no treatment (unsprayed control); 2) a single application of $\mathrm{P}-\mathrm{Ca}\left(250 \mathrm{mg} \cdot \mathrm{L}^{-1}\right.$ a.i.); 3) a single application of ETH $\left(175 \mathrm{mg} \cdot \mathrm{L}^{-1}\right.$ a.i.); or 4) a single application of a tank-mix of both products at the same concentrations as applied individually (terminal shoot length at time of applications - 'Attika': $23.8 \pm 0.7 \mathrm{~cm}$; 'Bing': $27.8 \pm 0.4 \mathrm{~cm}$; and 'Regina': $29.5 \pm 0.8 \mathrm{~cm}$ ). Shoot lengths were measured weekly on three marked terminal shoots per tree from 11 May to 12 Aug., by which time terminal buds were forming. Trunk circumferences were measured as in Trial 1. In April 2001, a sample limb was selected, basal limb circumference determined and flower buds were counted on all previous-season shoots and on all spurs on 2- and 3 -year-old wood (Forshey and Elfving, 1979). Flowering data were normalized based on limb cross-sectional area (LCSA).

Trial 3 (2000). 'Lapins'/Mazzard trees planted in 1997 near Quincy, Wash. (elevation $\approx 500 \mathrm{~m}, 6$ replicates) and carrying a few fruit per tree were treated on 24 May as follows: 1) no treatment (unsprayed control);2) a single application of $\mathrm{P}-\mathrm{Ca}\left(250 \mathrm{mg} \cdot \mathrm{L}^{-1}\right.$ a.i. $\left.) ; 3\right)$ a single application of ETH $\left(200 \mathrm{mg} \cdot \mathrm{L}^{-1}\right.$ a.i.); or 4) a single application of a tank-mix of both products at the same concentrations as applied individually (terminal shoots $28.7 \pm 0.5 \mathrm{~cm}$ at time of applications). Shoot lengths were measured weekly on three marked terminal 
shoots per tree from 1 May to mid-September, by which time terminal buds had formed. Trunk circumferences were measured as in Trial 1 . At the end of the growing season, terminal and lateral shoot lengths were measured on a single sample limb per tree (Forshey and Elfving, 1979), and limb circumference was taken near the limb base. In Apr. 2001, a similar limb was selected, basal limb circumference taken near the base, and flower buds were counted on all previous-season shoots and on all spurs on 2-, 3-, and 4-year-old wood. Shoot growth and flowering data were normalized using the appropriate LCSA values.

Trial4 (2000). Nonfruiting 'Bing'/Mazzard trees planted in 1997 nearWenatchee (elevation $\approx 490 \mathrm{~m}, 5$ replicates per treatment) were treated as follows: 1) no treatment (unsprayed control); 2) $\mathrm{P}-\mathrm{Ca}\left(125 \mathrm{mg} \cdot \mathrm{L}^{-1}\right.$ a.i.) on 17 May only (terminal shoots $21.5 \pm 0.7 \mathrm{~cm}) ; 3) \mathrm{P}-\mathrm{Ca}\left(250 \mathrm{mg} \cdot \mathrm{L}^{-1}\right.$ a.i.) on 17 May only; 4) a tank-mix of P-Ca (125 $\mathrm{mg} \cdot \mathrm{L}^{-1}$ a.i.) plus ETH (175 $\mathrm{mg} \cdot \mathrm{L}^{-1}$ a.i.) on 17 May only; 5) a tank-mix of P-Ca (250 mg $\cdot \mathrm{L}^{-1}$ a.i.) plus ETH ( $175 \mathrm{mg} \cdot \mathrm{L}^{-1}$ a.i.) on 17 May only; 6) $\mathrm{P}-\mathrm{Ca}\left(125 \mathrm{mg} \cdot \mathrm{L}^{-1}\right.$ a.i.) on 7 June only (terminal shoots $48.5 \pm 1.3 \mathrm{~cm})$; 7) P-Ca $(250$ $\mathrm{mg} \cdot \mathrm{L}^{-1}$ a.i.) on 7 June only; 8) a tank-mix of P-Ca $\left(125 \mathrm{mg} \cdot \mathrm{L}^{-1}\right.$ a.i. $)$ plus ETH $\left(175 \mathrm{mg} \cdot \mathrm{L}^{-1}\right.$ a.i.) on 7 June only; or 9) a tank-mix of P-Ca ( $250 \mathrm{mg} \cdot \mathrm{L}^{-1}$ a.i.) plus ETH $\left(175 \mathrm{mg} \cdot \mathrm{L}^{-1}\right.$ a.i. $)$ on 7 June only. Final shoot numbers and lengths, trunk circumference, and subsequent flower bud formation were measured as in Trial 3.

Trial 5 (2000). Nonfruiting 'Bing'/ Mazzard trees planted in 1998 near Pasco (elevation $\approx 260 \mathrm{~m}$, six replicates per treatment) were treated as follows: 1) no treatment (unsprayed control); 2) an application of a tank-mix of P-Ca (83 $\mathrm{mg} \cdot \mathrm{L}^{-1}$ a.i.) plus ETH (150 mg $\cdot \mathrm{L}^{-1}$ a.i.) on 3 May (terminal shoots 10 $15 \mathrm{~cm}$ ) and again on 25 May (control terminal shoots $38.0 \pm 0.6 \mathrm{~cm}$ ); or 3 ) an application of a tank-mix of P-Ca (125 mg. $\mathrm{L}^{-1}$ a.i.) plus ETH (150 $\mathrm{mg} \cdot \mathrm{L}^{-1}$ a.i.) on 3 May and again on 25 May. Lengths of five terminal shoots per tree were measured on 25 May, 1 June, and 21 June. At the end of the growing season, the length of each of 10 terminal shoots was measured on each tree. Trunk circumference and subsequent flower bud formation were measured as in Trial 3.

Trial 6 (2000). Nonfruiting 'Bing'/ Mazzard trees planted in 1997 near Wenatchee (elevation $\approx 490 \mathrm{~m}, 5$ replicates per treatment) were treated as follows: 1 ) no treatment (unsprayed control); 2) P-Ca (125 mg $\cdot \mathrm{L}^{-1}$ a.i.) on17 May (terminal shoots $22.1 \pm 0.2 \mathrm{~cm}$ ) and again on 7 June (control terminal shoots $48.6 \pm 0.6 \mathrm{~cm}) ; 3)$ a tank-mix of P-Ca (125 $\mathrm{mg} \cdot \mathrm{L}^{-1}$ a.i. $)$ plus ETH (200 $\mathrm{mg} \cdot \mathrm{L}^{-1}$ a.i.) on 17 May followed by an application of P-Ca (125 $\mathrm{mg} \cdot \mathrm{L}^{-1}$ a.i.) on 7 June; 4) P-Ca (125 $\mathrm{mg} \cdot \mathrm{L}^{-1}$ a.i.) on 17 May followed by a tank-mix of P-Ca (125 mg $\cdot \mathrm{L}^{-1}$ a.i.) plus ETH (200 mg. $\mathrm{L}^{-1}$ a.i.) on 7 June, or 5) a tank-mix of P-Ca (125 $\mathrm{mg} \cdot \mathrm{L}^{-1}$ a.i. $)$ plus ETH $\left(150 \mathrm{mg} \cdot \mathrm{L}^{-1}\right.$ a.i. $)$ on 17 May and again on 7 June. Final shoot numbers and lengths, trunk circumference, and subsequent flower bud formation were measured as in Trial 3. On 10 July 2001, all fruit from each test tree were harvested and weighed.
All data were subjected to analysis of variance (ANOVA) using the General linear models (GLM) program of the SAS statistical analysis package (SAS Inst., Cary, N.C.). Treatment means were separated using the Waller/Duncan Bayesian k-ratio mean separation procedure following a significant $\mathrm{F}$ test for each variable $(P \leq 0.05)$.

\section{Results}

Trial 1. 'Bing' terminal shoot extension growth was reduced by a single application of either P-Ca or ETH on 18 June, at which time ca. one-third of the total seasonal shoot growth had occurred (Fig. 1). The tank-mix of the two bioregulators greatly reduced shoot growth, more than either alone; the shoot-growth response to the tank-mix fits the criterion for a synergistic response (Colby, 1966). Trunk cross-sectional area (TCSA) enlargement was unaffected by treatment (data not shown). No bloom data were collected in this trial.

Trial 2. In the Yakima valley, untreated 'Attika' and 'Bing' trees on Mazzard were $\approx 50 \%$ more vigorous than the trees in all other trials, while 'Regina'/Mazzard was similar to the others (Fig. 2). Bioregulator applications were made to 'Attika' and 'Bing' when only one-fifth of the total seasonal shoot growth had occurred (Fig. 2, a and b), while about one-third of the total seasonal shoot growth had occurred in 'Regina' when treatments were applied (Fig. 2c). 'Attika' terminal extension growth rate was reduced by $\mathrm{P}-\mathrm{Ca}$, starting about 2 weeks after treatment and lasting for $\approx 3$ weeks (Fig. 2a). Adding ETH to P-Ca extended this reduction for an additional 3 weeks, but ETH alone had no effect. 'Bing' terminal extension growth rate was only slightly reduced by P-Ca or ETH alone, but was reduced for $\approx 3-4$ weeks by the tank-mix
(Fig. 2b). By the end of the growing season, there were only minor differences in terminal shoot extension growth, which did not suggest a synergistic response (Colby, 1966). 'Regina' terminal extension growth rate was not affected by any bioregulator treatment (Fig. 2c). TCSA enlargement and subsequent flowering in 2001 were not affected by any treatment in any cultivar (data not shown).

Trial 3. 'Lapins' terminal shoot extension growth was reduced by a single application of either P-Ca or ETH on 24 May, at which time less than one-third of the total seasonal shoot growth had occurred (Fig. 3). The tank-mix of the two bioregulators reduced shoot growth more than either alone, again fitting the criterion for a synergistic response (Colby, 1966). These results were similar to the response of 'Bing' in Trial 1. On a LCSA-normalized basis, the P-Ca treatment reduced mean shoot length and total shoot growth, but did not affect shoot number or TCSA enlargement (Table 1). ETH alone or in the tank-mix increased shoot number by a minor promotion of lateral budbreak on current season terminal shoots. The greater effect of ETH alone on this lateral budbreak resulted in total shoot growth and TCSA enlargement comparable to the control, despite its reduction of mean shoot length. Only the tank-mix reduced TCSA enlargement. Subsequent flowering in 2001 was sparse, with no apparent bioregulator treatment effects (data not shown).

Trial 4. Single applications of P-Ca alone (either 125 or $250 \mathrm{mg} \cdot \mathrm{L}^{-1}$ a.i.) in mid-May slowed 'Bing' terminal shoot extension for $\approx 5$ weeks following treatment, but terminal shoots continued to elongate for a short period beyond the time when untreated terminals ceased elongation (Fig. 4a). Tank-mix applications of P-Ca and ETH in mid-May stopped terminal extension elongation for $\approx 8$ weeks, after

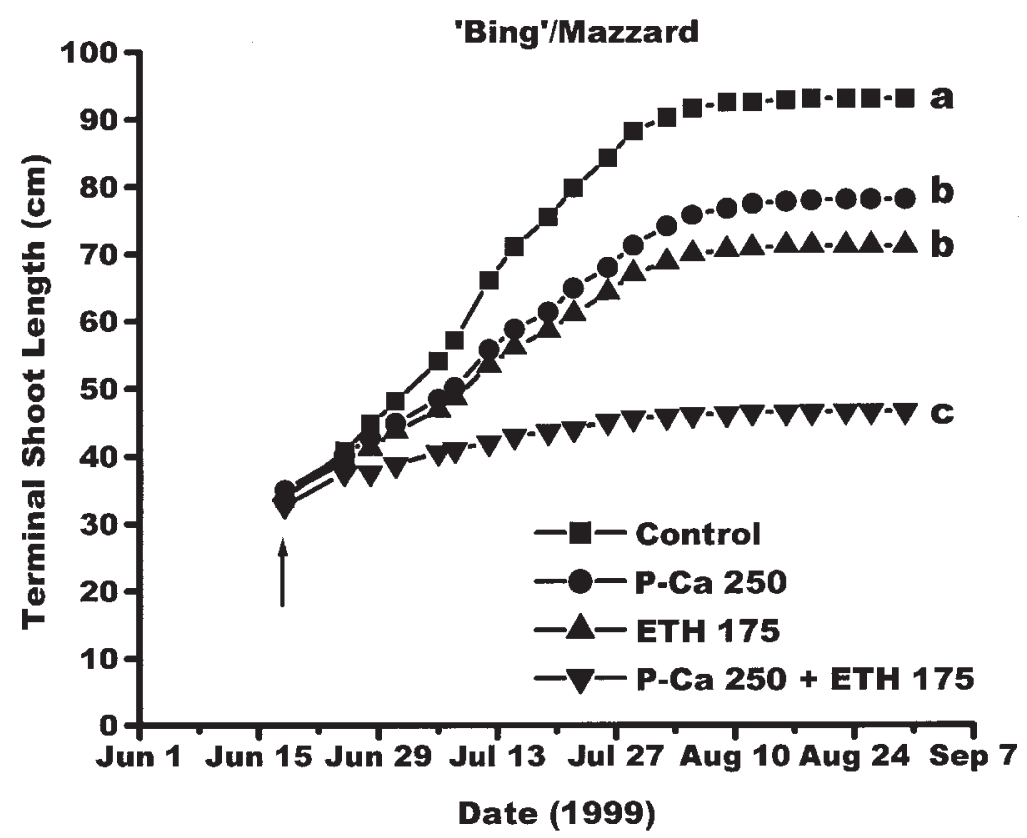

Fig. 1. Terminal shoot length of 'Bing'/Mazzard trees following single applications on 18 June 1999 (arrow) of P-Ca $\left(250 \mathrm{mg} \cdot \mathrm{L}^{-1}\right.$ a.i.), ETH $\left(175 \mathrm{mg} \cdot \mathrm{L}^{-1}\right.$ a.i.) or the tank mix (Trial 1). Final terminal shoot length values followed by different letters are significantly different by the Waller-Duncan Bayesian k-ratio test $(P \leq 0.05)$. 

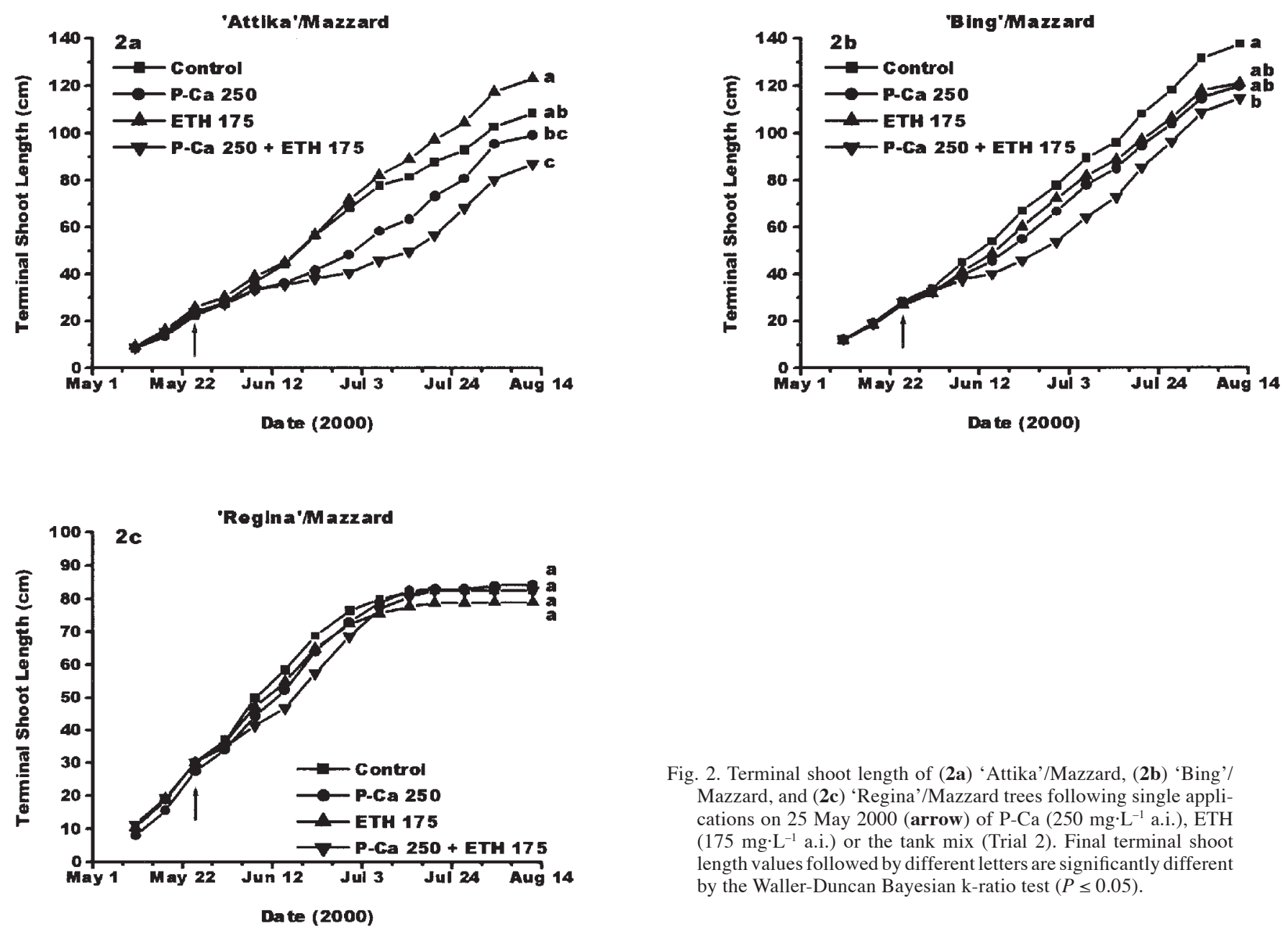

Fig. 2. Terminal shoot length of (2a) 'Attika'/Mazzard, (2b) 'Bing'/ Mazzard, and (2c) 'Regina'/Mazzard trees following single applications on 25 May 2000 (arrow) of P-Ca $\left(250 \mathrm{mg} \cdot \mathrm{L}^{-1}\right.$ a.i.), ETH $\left(175 \mathrm{mg} \cdot \mathrm{L}^{-1}\right.$ a.i.) or the tank mix (Trial 2). Final terminal shoot length values followed by different letters are significantly different by the Waller-Duncan Bayesian k-ratio test $(P \leq 0.05)$.

which a second flush took place. Application of P-Ca alone or in combination with ETH on 7 June, at which time about one-half of the total seasonal shoot growth had occurred, resulted in a cessation of terminal shoot extension with no further resumption (Fig. 4b). TCSA enlargement was not affected by any treatment (data not shown). Treatment with $\mathrm{P}-\mathrm{Ca}$ or $\mathrm{P}-\mathrm{Ca}+\mathrm{ETH}$ in May increased total flower bud density, due to increased flower number on previous season shoots but not on spurs on older wood (Table 2). Applications in June only slightly increased total flower bud density, due to slightly increased numbers on previous season shoots.

Trial 5. 'Bing' terminal shoot length and calculated mean daily elongation rate were reduced by both tank-mix treatments during the month following the second treatment, but final terminal shoot length differences were minor (data not shown). However, both double applications of $\mathrm{P}-\mathrm{Ca}+\mathrm{ETH}$ reduced TCSA enlargement (Table 3). The treatment with the higher concentration of $\mathrm{P}-\mathrm{Ca}$ also increased subsequent flower bud density on previous season shoots.

Trial 6. Application of P-Ca on 17 May, at which time ca. one-quarter of the total seasonal shoot growth had occurred, reduced 'Bing'terminal shoot elongation rate by $\approx 50 \%$ during the subsequent 3 weeks (Fig. 5). The repeat application of $\mathrm{P}-\mathrm{Ca}$ maintained this reduced rate, but growth continued long after that of the controls, until final terminal shoot length was not significantly different. When ETH was added on either (at $200 \mathrm{mg} \cdot \mathrm{L}^{-1}$ a.i.) or both (at
$150 \mathrm{mg} \cdot \mathrm{L}^{-1}$ a.i.) dates of P-Ca application, shoot elongation ceased rapidly. Trees treated with ETH on the earlier date eventually initiated a second, relatively weak shoot growth flush

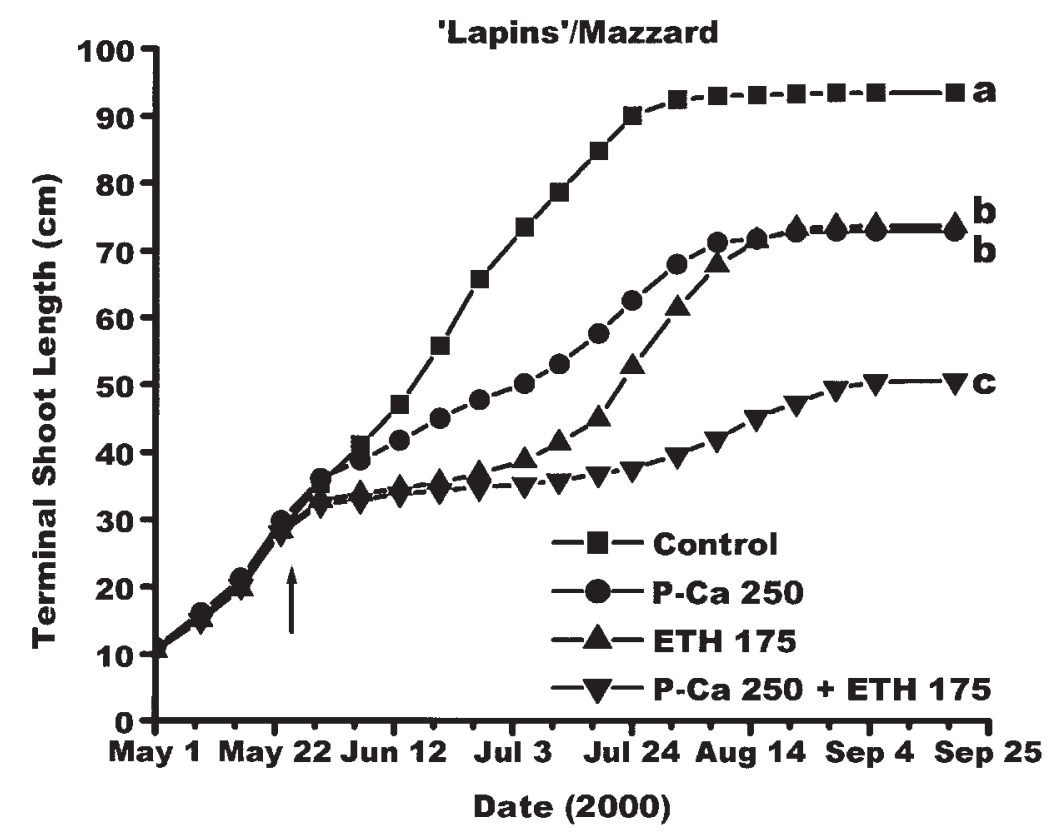

Fig. 3. Terminal shoot length of 'Lapins'/Mazzard trees following single applications on 24 May 2000 (arrow) of P-Ca (250 mg $\cdot \mathrm{L}^{-1}$ a.i.), ETH $\left(200 \mathrm{mg} \cdot \mathrm{L}^{-1}\right.$ a.i.) or the tank mix (Trial 3). Final terminal shoot length values followed by different letters are significantly different by the Waller-Duncan Bayesian k-ratio test $(P \leq 0.05)$ 
in August, whether they received a later ETH application or not. Trees receiving ETH only on the later date never resumed shoot growth.

Double application of $\mathrm{P}-\mathrm{Ca}$ alone reduced both terminal and lateral shoot lengths; however, when combined with a nonsignificant increase in shoot number, total shoot growth was not different from the control (Table 4). The addition of ETH, regardless of timing, reduced both terminal and lateral shoot lengths as well as total shoot growth. There were no treatment effects on TCSA enlargement (data not shown).

Double application of P-Ca alone did not affect subsequent flowering or yield in 2001 (Table 5). The earlier addition of ETH increased flower buds on previous season shoots but not on spurs. The later addition of ETH increased flower buds on both previous season shoots and spurs, but not significantly. Supplementing P-Ca with ETH on both application dates significantly increased flower bud formation on both shoots and spurs, leading to about a 3fold increase in total flowering, which carried through to a similarly increased yield (though higher variability in the latter parameter precluded statistical significance). When yields were adjusted for tree-to-tree variation in tree size (yield efficiency), the double applications of the tank-mix of P-Ca+ETH resulted in significantly higher yield efficiency.

\section{Discussion}

Both P-Ca and ETH, alone and in combination, reduced sweet cherry shoot extension growth in the majority of our trials, with substantial variability in both magnitude and duration of shoot extension growth reduction resulting from application number, concentration, timing, and cultivar. Growth inhibition from single applications generally did not persist for the entire growing season,
Table 1. Effects of single applications of P-Ca, ETH, or P-Ca plus ETH on limb-sample shoot growth and trunk enlargement in 4th-leaf 'Lapins'/Mazzard sweet cherry trees (Trial 3).

\begin{tabular}{|c|c|c|c|c|c|c|c|}
\hline \multirow{2}{*}{$\begin{array}{l}\text { Treatment } \\
\left(\mathrm{mg} \cdot \mathrm{L}^{-1}\right)^{\mathrm{x}}\end{array}$} & \multicolumn{2}{|c|}{ Shoots $/ \mathrm{cm}^{2}$ LCSA $^{2}$} & \multirow{2}{*}{$\begin{array}{l}\text { Mean shoot } \\
\text { length }(\mathrm{cm})\end{array}$} & \multicolumn{2}{|c|}{$\begin{array}{r}\mathrm{TCSA}^{y} \\
\left(\mathrm{~cm}^{2}\right)\end{array}$} & \multicolumn{2}{|c|}{ TCSA increment } \\
\hline & Number & Length $(\mathrm{cm})$ & & Spring & Fall & $\mathrm{cm}^{2}$ & $\%$ \\
\hline Control & $0.5 \mathrm{c}$ & $34 \mathrm{a}$ & $72 \mathrm{a}$ & $31.0 \mathrm{a}$ & $70.8 \mathrm{a}$ & $39.8 \mathrm{ab}$ & $137 \mathrm{a}$ \\
\hline P-Ca 250 & $0.6 \mathrm{bc}$ & $25 \mathrm{~b}$ & $42 \mathrm{bc}$ & $26.5 \mathrm{a}$ & $62.1 \mathrm{~b}$ & $35.6 \mathrm{bc}$ & $139 \mathrm{a}$ \\
\hline ETH 200 & $0.9 \mathrm{a}$ & $35 \mathrm{a}$ & $44 \mathrm{~b}$ & $28.5 \mathrm{a}$ & $69.5 \mathrm{ab}$ & $41.0 \mathrm{a}$ & $147 \mathrm{a}$ \\
\hline $\mathrm{P}-\mathrm{Ca}+\mathrm{ETH}$ & $0.7 \mathrm{ab}$ & $24 \mathrm{~b}$ & $33 \mathrm{c}$ & $31.8 \mathrm{a}$ & $66.7 \mathrm{ab}$ & $34.9 \mathrm{c}$ & $111 \mathrm{~b}$ \\
\hline
\end{tabular}

${ }^{2}$ LCSA $=$ limb cross-sectional area, $\mathrm{cm}^{2}$.

${ }^{\mathrm{T}} \mathrm{TCSA}=$ trunk cross-sectional area, $\mathrm{cm}^{2}$.

${ }^{\mathrm{x}}$ Mean separation in columns by Waller-Duncan Bayesian k-ratio test following significant $\mathrm{F}$ test $(P \leq 0.05)$.

Table 2. Effects of single applications of P-Ca or P-Ca plus ETH on flower bud formation in 4th-leaf 'Bing'/Mazzard sweet cherry trees (Trial 4).

\begin{tabular}{lccc}
\hline Treatment & \multicolumn{3}{c}{ Flower bud no./cm LCSA $^{\mathrm{z}}$} \\
\cline { 2 - 4 }$\left(\mathrm{mg} \cdot \mathrm{L}^{-1}\right)^{\mathrm{y}}$ & $0.4 \mathrm{~d}$ & $1.2 \mathrm{a}$ & $1.6 \mathrm{~b}$ \\
\hline Control & $2.2 \mathrm{ab}$ & $2.2 \mathrm{a}$ & $4.4 \mathrm{ab}$ \\
P-Ca 125, 17 May & $1.6 \mathrm{bc}$ & $1.6 \mathrm{a}$ & $3.2 \mathrm{ab}$ \\
P-Ca 250, 17 May & $3.0 \mathrm{a}$ & $2.5 \mathrm{a}$ & $5.5 \mathrm{a}$ \\
P-Ca 125 + ETH 175, 17 May & $2.6 \mathrm{ab}$ & $2.0 \mathrm{a}$ & $4.6 \mathrm{ab}$ \\
P-Ca 250 + ETH 175, 17 May & $1.6 \mathrm{~b}-\mathrm{d}$ & $2.2 \mathrm{a}$ & $3.8 \mathrm{ab}$ \\
P-Ca 125, 7 June & $0.9 \mathrm{~cd}$ & $1.8 \mathrm{a}$ & $2.7 \mathrm{ab}$ \\
P-Ca 250, 7 June & $1.5 \mathrm{~b}-\mathrm{d}$ & $1.1 \mathrm{a}$ & $2.6 \mathrm{ab}$ \\
P-Ca 125 + ETH 175, 7 June & $1.7 \mathrm{bc}$ & $2.0 \mathrm{a}$ & $3.7 \mathrm{ab}$ \\
P-Ca 250 + ETH 175, 7 June & &
\end{tabular}

${ }^{2} \mathrm{LCSA}=$ limb cross-sectional area, $\mathrm{cm}^{2}$.

${ }^{y}$ Mean separation in columns by Waller-Duncan Bayesian k-ratio test following significant $\mathrm{F}$ test $(P \leq 0.05)$.

Table 3. Effects of double applications of P-Ca plus ETH on trunk enlargement and flower bud formation in 3rd-leaf 'Bing'/Mazzard sweet cherry trees (Trial 5).

\begin{tabular}{|c|c|c|c|c|c|c|c|}
\hline \multirow{2}{*}{$\begin{array}{l}\text { Treatment } \\
\left(\mathrm{mg} \cdot \mathrm{L}^{-1}\right)^{\mathrm{x}, \mathrm{w}}\end{array}$} & \multicolumn{2}{|c|}{$\begin{array}{c}\mathrm{TCSA}^{\mathrm{z}} \\
\mathrm{cm}^{2}\end{array}$} & \multicolumn{2}{|c|}{$\begin{array}{c}\text { TCSA } \\
\text { increment }\end{array}$} & \multicolumn{3}{|c|}{$\begin{array}{c}\text { Flower bud } \\
\text { number/cm² LCSA }\end{array}$} \\
\hline & Spring & Fall & $\left(\mathrm{cm}^{2)}\right.$ & $(\%)$ & 1-year shoots & Spurs & Total \\
\hline Control & $43.1 \mathrm{a}$ & $92.2 \mathrm{a}$ & $49.0 \mathrm{a}$ & $114 \mathrm{a}$ & $1.1 \mathrm{~b}$ & $4.2 \mathrm{a}$ & 5.3 \\
\hline P-Ca $83+$ ETH 150 & $42.3 \mathrm{a}$ & $86.1 \mathrm{a}$ & $43.8 \mathrm{~b}$ & $104 \mathrm{~b}$ & $2.3 \mathrm{ab}$ & $3.2 \mathrm{a}$ & $5.5 \mathrm{a}$ \\
\hline P-Ca $125+$ ETH 150 & $44.7 \mathrm{a}$ & $86.6 \mathrm{a}$ & $41.9 \mathrm{~b}$ & $94 \mathrm{c}$ & $3.9 \mathrm{a}$ & $5.5 \mathrm{a}$ & $9.3 \mathrm{a}$ \\
\hline
\end{tabular}

${ }^{\text {zTCSA }}=$ trunk cross-sectional area $\mathrm{cm}^{2}$.

${ }^{y}$ LCSA $=$ limb cross-sectional area, $\mathrm{cm}^{2}$.

${ }^{x}$ Mean separation in columns by Waller-Duncan Bayesian k-ratio test following significant $\mathrm{F}$ test $(P \leq$ $0.05)$.

${ }^{\mathrm{w}}$ Applications 3 and 25 May 2000.
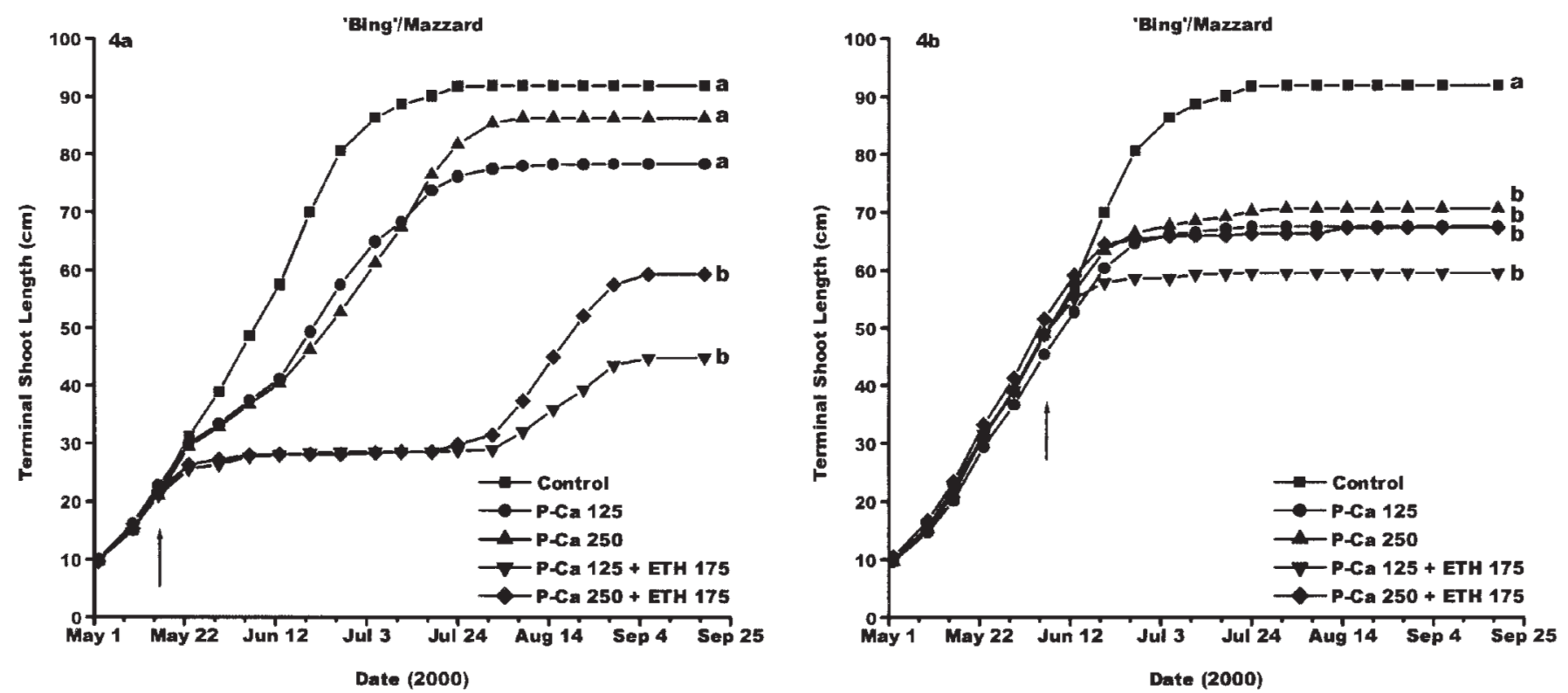

Fig. 4. Terminal shoot length of 'Bing'/Mazzard trees following (4a) single early applications on 17 May 2000 (arrow) or (4b) delayed applications on 7 June 2000 (arrow) of P-Ca (125 or $250 \mathrm{mg} \cdot \mathrm{L}^{-1}$ a.i.) or P-Ca (125 or $250 \mathrm{mg} \cdot \mathrm{L}^{-1}$ a.i.) plus ETH (175 mg. $\mathrm{L}^{-1}$ a.i.) (Trial 4). Final terminal shoot length values followed by different letters are significantly different by the Waller-Duncan Bayesian k-ratio test $(P \leq 0.05)$. 
a result consistent with some reports of $\mathrm{P}-\mathrm{Ca}$ activity in apple (Malus $\times$ domestica Borkh.) (Basak and Rademacher, 2000; Byers and Yoder, 1999; Evans et al., 1997; Unrath, 1999) and pear (Pyrus communis L.) (Elfving et al., 2002). The most dramatic inhibition usually was seen from a synergistic interaction of the two bioregulators.

When single applications of P-Ca, ETH, or the tank-mix were applied when $\approx 20 \%$ to $35 \%$ of seasonal shoot growth had already occurred, the four sweet cherry cultivars under study (Trials 1-3) responded differently. 'Bing' and 'Lapins', although a year different in age and a season different in application, exhibited very similar shoot elongation responses to the treatments, including synergistic inhibition with the tank-mix. However, the extremely vigorous 'Bing' trees in Trial 2 responded only slightly to all three treatments when they were applied at an earlier stage of growth. Furthermore, the 'Regina' trees in Trial 2 that were at the most similar stage of growth to the responsive trees in Trials 1 and 3 exhibited no growth effects from any treatment. The third cultivar in Trial 2, 'Attika', was nearly as vigorous as the 'Bing' trees in the trial, yet was responsive to $\mathrm{P}-\mathrm{Ca}$ and the P-Ca+ETH treatments, but not the ETH treatment alone. The single bioregulator applications, alone or as a tank-mix, generally had little or no effect on subsequent year flowering. The subtleties of cultivar differences, inherent tree vigor, growth stage at application, and possible climatic differences (elevational and latitudinal differences between north-central and southern Wash.) merit further study with respect to growth control.

However, since 'Bing' comprises the majority of sweet cherry production in the PNW, the remaining experiments (Trials 4-6) focused on further refining the treatments that appear to hold the greatest potential for modification of young tree growth and flowering habit for high density orchards on vigorous rootstocks, i.e., multiple applications involving the synergistic response of both bioregulators. When the tankmix of P-Ca+ETH was applied in May, 'Bing' shoot growth ceased but a distinct, weak second flush usually appeared late in the growing season. When the tank-mix was applied in June, shoot growth ceased entirely for the remainder of the season. Effects on TCSA enlargement were variable (reduced in Trials 3 and 5, no effect in Trials 4 and 6).

Sweet cherry flower buds occur laterally on basal portions of previous-season shoots as well as on spurs on older wood. Once flower bud formation begins on young, previously nonfruiting trees, reproductive competency is attained and flower bud formation continues; hence, the interest in methods to promote early flowering. Certain cultural manipulations antagonistic to shoot elongation (i.e., deficit irrigation, limb bending) generally promote earlier flowering; Guimond et al. (1998) have suggested that this may involve removal of apical hormonal and/or sink effects, thereby favoring flower initiation. In our experiments, growth inhibition by $\mathrm{P}-\mathrm{Ca}$ alone, applied either once or twice, did not improve flowering in any of the six trials, which is consistent with

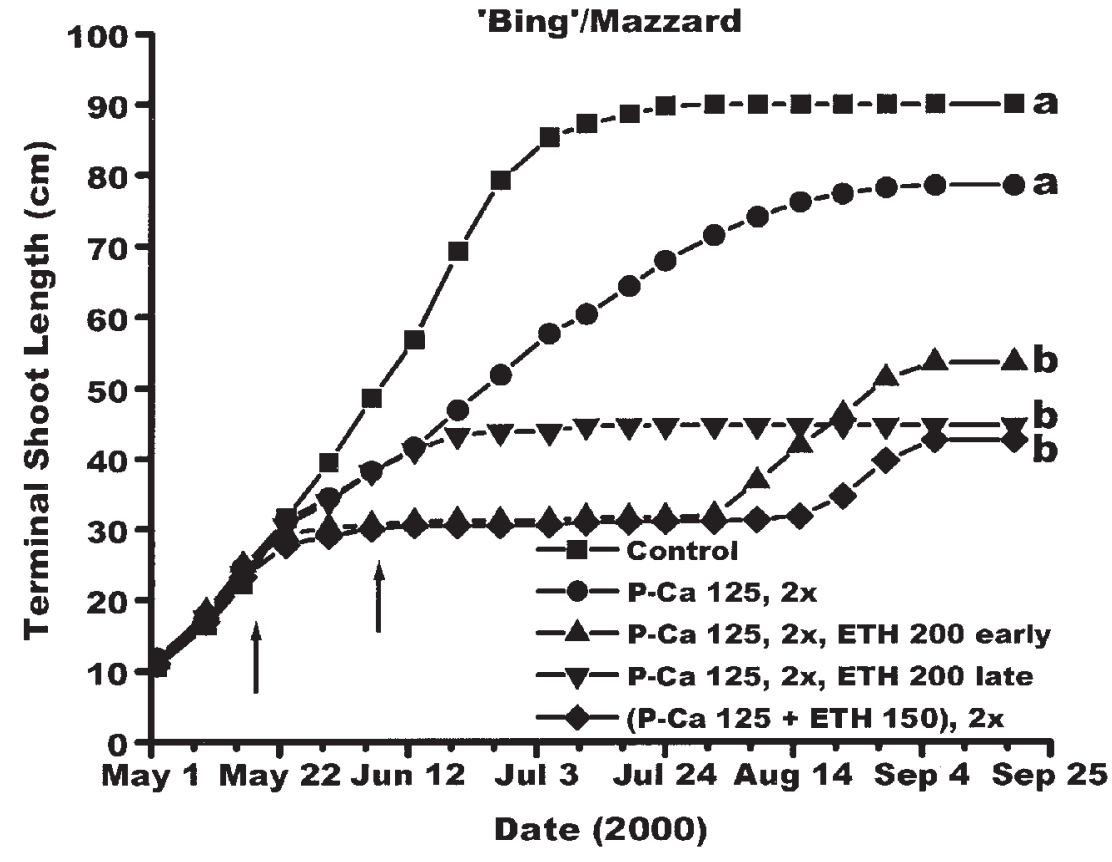

Fig. 5. Terminal shoot length of 'Bing'/Mazzard trees following double applications of P-Ca (125 $\mathrm{mg} \cdot \mathrm{L}^{-1}$ a.i.) on 17 May and 7 June 2000 . One set of P-Ca - treated trees also received ETH (200 mg. $\mathrm{L}^{-1}$ a.i. $)$ on the first P-Ca application date, another also received ETH $\left(200 \mathrm{mg} \cdot \mathrm{L}^{-1}\right.$ a.i. $)$ on the second P-Ca application date, and a third set of trees received ETH $\left(150 \mathrm{mg} \cdot \mathrm{L}^{-1}\right.$ a.i.) combined with P-Ca on both application dates (Trial 6). Final terminal shoot length values followed by different letters are significantly different by the Waller-Duncan Bayesian k-ratio test $(P \leq 0.05)$. previous reports of $\mathrm{P}-\mathrm{Ca}$ effects on flowering in apple and pear (Basak and Rademacher, 2000; Owens and Stover, 1999; Sugar et al., 2002).

Single applications of ETH alone also had no effect on flowering. However, tank-mixing ETH with P-Ca increased 'Bing' flower bud formation on previous-season shoots (but not spurs) when applied in May, slightly on both shoots and spurs if applied once in June, and significantly on both shoots and spurs when applied as double applications. Interestingly, the second flush of vegetative growth (which occurred only with treatments supplemented with ETH in May) did not ap-
Table 4. Effects of double applications of P-Ca with or without supplemental ETH on limb-sample shoot growth in 4th-leaf 'Bing'/Mazzard sweet cherry trees (Trial 6).

\begin{tabular}{lccccc}
\hline & \multicolumn{2}{c}{ Shoots/cm ${ }^{2}$ LCSA $^{z}$} & & \multicolumn{2}{c}{ Mean shoot length $(\mathrm{cm})$} \\
\cline { 2 - 3 } \cline { 5 - 6 } Treatment $\left(\mathrm{mg} \cdot \mathrm{L}^{-1}\right)^{\mathrm{y}}$ & Number & Length $(\mathrm{cm})$ & & Terminal shoots & Lateral shoots \\
\hline Control & $1.1 \mathrm{a}$ & $100 \mathrm{a}$ & & $146 \mathrm{a}$ & $86 \mathrm{a}$ \\
P-Ca 125, 17 May, 7 June & $1.6 \mathrm{a}$ & $107 \mathrm{a}$ & & $114 \mathrm{~b}$ & $63 \mathrm{~b}$ \\
P-Ca 125, 17 May, 7 June + ETH 200 & & & & & \\
$\quad$ 17 May only & $1.8 \mathrm{a}$ & $71 \mathrm{~b}$ & & $62 \mathrm{c}$ & $39 \mathrm{c}$ \\
P-Ca 125, 17 May, 7 June + ETH 200 & & & & $51 \mathrm{c}$ & $45 \mathrm{c}$ \\
$\quad$ 7 June only & $1.3 \mathrm{a}$ & $61 \mathrm{~b}$ & & $51 \mathrm{c}$ & $36 \mathrm{c}$ \\
P-Ca 125 + ETH 150, 17 May, 7 June & $1.7 \mathrm{a}$ & $65 \mathrm{~b}$ & &
\end{tabular}

${ }^{\mathrm{z}} \mathrm{LCSA}=$ limb cross-sectional area, $\mathrm{cm}^{2}$.

${ }^{y}$ Mean separation in columns by Waller-Duncan Bayesian k-ratio test following significant $\mathrm{F}$ test $(P \leq$ $0.05)$.

Table 5. Effects of double applications of P-Ca with or without supplemental ETH in 2000 on flowering and yield in 4th-leaf 'Bing'/Mazzard sweet cherry trees in 2001 (Trial 6).

\begin{tabular}{|c|c|c|c|c|c|}
\hline \multirow{2}{*}{$\begin{array}{l}\text { Treatment } \\
\left(\mathrm{mg} \cdot \mathrm{L}^{-1}\right)^{\mathrm{y}}\end{array}$} & \multicolumn{3}{|c|}{ Flower bud number $/ \mathrm{cm}^{2} \mathrm{LCSA}^{\mathrm{z}}$} & \multicolumn{2}{|c|}{ Yield } \\
\hline & 1-year-old shoots & Spurs & Total & Per tree $(\mathrm{kg})$ & $\mathrm{g} / \mathrm{cm}^{2} \mathrm{TCSA}^{\mathrm{x}}$ \\
\hline Control & $1.5 \mathrm{bc}$ & $0.9 \mathrm{~b}$ & $2.4 \mathrm{bc}$ & $4.5 \mathrm{a}$ & $46 \mathrm{~b}$ \\
\hline $\begin{array}{l}\text { P-Ca 125, } 17 \text { May, } 7 \text { June } \\
\text { P-Ca 125, } 17 \text { May, }\end{array}$ & $0.7 \mathrm{c}$ & $0.7 \mathrm{~b}$ & $1.4 \mathrm{c}$ & $5.3 \mathrm{a}$ & $43 \mathrm{~b}$ \\
\hline $\begin{array}{l}7 \text { June + ETH 200, } 17 \text { May only } \\
\text { P-Ca 125, } 17 \text { May, }\end{array}$ & $3.0 \mathrm{a}$ & $1.1 \mathrm{~b}$ & $4.1 \mathrm{a}-\mathrm{c}$ & $6.2 \mathrm{a}$ & $69 \mathrm{ab}$ \\
\hline $\begin{array}{l}7 \text { June + ETH 200, } 7 \text { June only } \\
\text { P-Ca } 125 \text { + ETH 150, } 17 \text { May, }\end{array}$ & $2.7 \mathrm{ab}$ & $2.9 \mathrm{ab}$ & $5.6 \mathrm{ab}$ & $6.6 \mathrm{a}$ & $78 \mathrm{ab}$ \\
\hline 7 June & $3.3 \mathrm{a}$ & $4.5 \mathrm{a}$ & $7.8 \mathrm{a}$ & $12.8 \mathrm{a}$ & $117 \mathrm{a}$ \\
\hline
\end{tabular}

${ }^{\mathrm{z}} \mathrm{LCSA}=$ limb cross-sectional area, $\mathrm{cm}^{2}$.

y Mean separation in columns by Waller-Duncan Bayesian k-ratio test following significant $\mathrm{F}$ test $(P \leq 0.05)$.

${ }^{\mathrm{x}} \mathrm{TCSA}=$ trunk cross-sectional area, $\mathrm{cm}^{2}$. 
pear to be antagonistic to flowering, since these treatments showed increased flower bud numbers. Different flowering effects between timings of supplementary ETH application suggest that ethylene-based early cessation of growth may be associated with flower formation on previous-season shoots, while later growth cessation may be associated with spur flower formation; once these "windows" of meristematic determination have occurred, a later growth flush may not reverse the earlier initiation. Higher concentrations of ETH than those used here might be more effective for controlling growth and influencing flowering, but would increase the risk of producing severe gummosis (Modlibowska, 1973). There was little evidence of ETH-induced gummosis in any of the trials reported here.

The resultant increase in 'Bing' fruiting and canopy yield efficiency when P$\mathrm{Ca}+\mathrm{ETH}$ promoted flowering indicates that these bioregulators may be used to stimulate more precocious cropping in young 'Bing' sweet cherry trees on Mazzard seedling rootstock. Further applied research is needed to optimize these treatments for differences among sweet cherry cultivars, climatic sites, or both, as well as both fundamental and applied research to clarify the interactive and developmental effects of these bioregulators on flower initiation.

\section{Literature Cited}

Basak, A. and W. Rademacher. 2000. Growth regulation of pome and stone fruit trees by use of prohexadione-Ca. Acta Hort. 514:41-50.

Byers, R.E. 1993. Controlling growth of bearing apple trees with ethephon. HortScience 28: 1103-1105.

Byers, R.E. and K.S. Yoder. 1999. Prohexadione-calcium inhibits apple, but not peach, tree growth but has little influence on apple fruit thinning or quality. HortScience 34: 1205-1209.

Colby, S.R. 1966. Calculating synergistic and antagonistic responses of herbicide combinations. Weeds 25:20-22.

Edgerton, L.J. and W.J. Greenhalgh. 1969. Regulation of growth, flowering and fruit abscission with 2-chloroethanephosphonic acid. J. Amer. Soc. Hort. Sci. 94:11-14.

Elfving, D.C., D. Sugar, and D. Faubion. 2002. Pear tree shoot growth patterns in relation to chemical control of vegetative growth with prohexadione-calcium (Apogee ${ }^{\circledR}$ ). Acta Hort. 596:711-716.

Evans, J.R., R.R. Evans, C.L. Regusci, and W. Rademacher. 1999. Mode of action, metabolism and uptake of BAS $125 \mathrm{~W}$, prohexadione-calcium. HortScience 34:1200-1201.

Evans, R.R., J.R. Evans, and W. Rademacher. 1997. Prohexadione-calcium for suppression of vegetative growth in eastern apples. Acta Hort. 451:663-666.

Facteau, T.J. and N.E. Chestnut. 1991. Growth, fruiting, flowering and fruit quality of sweet cherries treated with paclobutrazol. HortScience 26:276-278.

Facteau, T.J. and K.E. Rowe. 1979. Growth, flowering and fruit set responses of sweet cherries to daminozide and ethephon. HortScience 14: 234-236.

Forshey, C.G. and D.C. Elfving. 1979. Branch samples for yield and fruit size comparisons in apple. HortScience 14:143-144.

Grzyb, Z.S. 1982. Growth and rooting of Brompton plum, F12/1 cherry and M.26 apple clonal rootstocks. II. Effect of Ethrel, CCC and Alar on the pattern of shoot growth and the initiation of adventitious roots. Fruit Sci. Rpts. 9(1):1-11.

Guimond, C.M., G.A. Lang, and P.K. Andrews. 1998. Timing and severity of summer pruning affects flower initiation and shoot regrowth in sweet cherry. HortScience 33:647-649.

Lang, G.A. 2000. Precocious, dwarfing, and productive-How will new cherry rootstocks impact the sweet cherry industry? HortTech- nology 10:719-725.

Looney, N.E. and J.E. McKellar. 1987. Effect of foliar- and soil-applied paclobutrazol on vegetative growth and fruit quality of sweet cherries. J. Amer. Soc. Hort. Sci. 112:71-76.

Modlibowska, I. 1973. Effect of growth regulators on plum and cherry trees. Acta Hort. 34: 203-206.

Owens, C.L. and E. Stover. 1999. Vegetative growth and flowering of young apple trees in response to Prohexadione-calcium. HortScience 34:1194-1196.

Proebsting, E.L. Jr. and H.H. Mills. 1976. Effect of daminozide on growth, maturity, quality and yield of sweet cherries. J. Amer. Soc. Hort. Sci. 101:175-179.

Rademacher, W. 2000. Growth retardants: Effects on gibberellin biosynthesis and other metabolic pathways. Annu. Rev. Plant Physiol. Plant Mol. Biol. 51:501-531.

Stan, S., N. Burloi, I. Popescu, N. Feneanu, and M. Cotorobai. 1989. Performance of paclobutrazol (Cultar) in controlling vegetative growth and cropping of stone fruits. Acta Hort. 239: 221-228.

Sugar, D., D.C. Elfving, and E.A. Mielke. 2002. Effects of prohexadione-calcium on blossoming, production and fruit quality in pear. Acta Hort. 596:757-760.

Unrath, C.R. 1999. Prohexadione-Ca: A promising chemical for controlling vegetative growth of apples. HortScience 34:1197-1200.

Webster, A.D., J.D. Quinlan, and P.J. Richardson. 1986. The influence of paclobutrazol on the growth and cropping of sweet cherry cultivars. I. The effect of annual soil treatment on the growth and cropping of cv. Early Rivers. J. Hort. Sci. 61:471-478.

Williams, M.W. 1972. Induction of spur and flower bud formation in young apple trees with chemical growth regulators. J. Amer. Soc. Hort. Sci. 97:210-212.

Yoder, K.S., S.S. Miller, and R.E. Byers. 1999. Suppression of fireblight in apple shoots by prohexadione-calcium following experimental and natural inoculation. HortScience 34:1202-1204. 